\title{
Systematic revision and phylogenetic assessment of the foraminiferal family Globivalvulinidae
}

Valerio Gennari, Marco Cherin, and Roberto Rettori

Acta Palaeontologica Polonica 63 (4), 2018: 807-814 doi:https://doi.org/10.4202/app.00511.2018

We present a systematic and phylogenetic revision of the Carboniferous-Permian subfamilies usually included within the family Globivalvulinidae (superfamily Biseriamminoidea), based for the first time on the interrelation between a morphological/structural approach (traditionally used for this fossil group) and a cladistic analysis (rarely applied to Palaeozoic Foraminifera). The systematic review of the globivalvulinid genera defines a new composition of the already existing four subfamilies of Globivalvulinidae (Globivalvulininae, Paraglobivalvulininae, Dagmaritinae, and Paradagmaritinae). The phylogenetic analysis of the Globivalvulinidae is aimed at understanding and reconstructing the relationships between its four subfamilies. The resulting phylogenetic tree is obtained by means of fifteen qualitative and one quantitative characters. The analysis shows that the Globivalvulinidae represents a monophyletic clade having the subfamily Globivalvulininae as the first taxon to branch out. The close affinity between the Dagmaritinae and Paradagmaritinae is confirmed.

Key words: Foraminifera, Biseriamminoidea, Globivalvulinidae, cladistics, phylogeny, taxonomy, Palaeozoic.

Valerio Gennari [valeriogennari@tiscali.it], Marco Cherin [marco.cherin@unipg.it ], and Roberto Rettori [roberto.rettori@unipg.it], University of Perugia, Dipartimento di Fisica e Geologia, Via Pascoli, 06123 Perugia, Italy.

This is an open-access article distributed under the terms of the Creative Commons Attribution License (for details please see creativecommons.org), which permits unrestricted use, distribution, and reproduction in any medium, provided the original author and source are credited. 
For Full text $(2,415.2 \mathrm{kB})$ 